\title{
O resgate da doutrina social na práxis das primeiras comunidades cristãs
}

\author{
Orientador: Prof. André Luiz Rodrigues da Silva \\ Pesquisador: Jose Antonio Jacinto Ferreira \\ Fonte: $\mathrm{CNPq}$
}

\section{Introdução}

As origens do cristianismo estão marcadas, desde o seu período mais remoto, pelos resultados da experiência que a comunidade fez com Jesus Cristo, interpretando, sobretudo as suas palavras e os seus gestos. Não poucas, nem desconsideráveis, foram as mudanças sociais de grande significado que surgiram a partir daquela experiência originária.

As primeiras comunidades cristãs nasceram com o propósito de permanecer praticando o modo de viver daquele que encarnou a misteriosa presença de Deus entre eles. Para eles, era necessário e fundamental que se mantivessem perseverando uma dinâmica de abertura, comunhão, fraternidade e solidariedade de acordo com os mesmos critérios que observaram, o que naturalmente permitiu a autorreflexão quanto a prática da justiça social.

Entretanto, essa proposta de forma de vida comunitária deveria ser capaz de superar a rejeição sobre o discurso religioso com reflexos na vida social, conforme algumas correntes filosóficas que foram sendo propagadas desde a Grécia antiga e que, a seu modo, sedimentavam-se esta dicotomia que já havia 7 séculos, onde buscava-se o saber e o conhecimento, e expurgava-se as antigas opiniões especulativa transmitidas por mera tradição.

Questões tais como o que seria o bem comum e como se poderia organizar socialmente têm sido debatidas desde de então. Também pode-se dizer que as respostas a essas questões fundamentais são indispensáveis para entender os diferentes modos de ser do mundo atual, em especial, quanto aos aspectos políticos e econômicos. Cada cultura e cada indivíduo produzem a sua interpretação do mundo segundo a máxima de Protágoras, que afirmava que o homem (e suas experiências) passa a ser a medida de todas as coisas. 
A sociedade atual se mostra fortemente secularizada. Assim, com dificuldade se percebe a efetiva presença dos valores cristãos em suas estruturas sociais, haja vista tamanha injustiça dominante. Neste aspecto, também dentro do próprio Cristianismo, as práticas sociais, que eventualmente tenham se distanciado ou perdido as suas raízes, acabam por se remeter a um conjunto de práticas abstratas que continuam sendo elaboradas ao longo da história.

\section{Objetivos}

Os objetivos são quatro:

Primeiro, pesquisar a doutrina social que está presente nas primeiras comunidades cristãs e apresenta-la para a sociedade atual, sobre como era o seu modo de vida, conforme os poucos documentos existentes elaborados nos primeiros séculos do cristianismo. Isso segue as orientações do Projeto de Pesquisa do Prof. André Luiz Rodrigues da Silva intitulado "Aplicação da metodologia patrística ao pensamento contemporâneo";

Segundo, além da questão social, procurar atender também à questão espiritual ao levantar uma forma de evangelização mais atualizada e atuante, não apenas com base teórica, e sim de forma mais prática, levantando argumentos e incentivos para um engajamento maior dos atuais agentes sociais, e também por uma cultura que valorize mais a dignidade humana e, por consequência, se tornando mais justa;

Terceiro, fazer com que esse estudo se abra para uma aproximação comparativa entre instituições atuais, não só eclesiásticas, e aquelas que tiveram sua origem relacionada de alguma forma com o cristianismo;

Enfim, tornar a preparação desse estudo como material qualificado com a finalidade de ser publicado em revista de pesquisas produzidas pelos discentes do departamento de Teologia da PUC-Rio. 